\section{Religión y política: las redes sociales \\ del catolicismo post-conciliar \\ y los Montoneros, 1966-1973 \\ Luis Miguel Donatello}

Luis Miguel Donatello es Becario de Formación de Postgrado del CONICET y Docente de la Facultad

de Ciencias Sociales de la Universidad de Buenos Aires; Marcelo T. de Alvear 2230, Ciudad de Buenos Aires, Argentina; tel: (54) (011) 4508-3800.

E-mail: luis_donatello@ciudad.com.ar

\section{Resumen}

Este artículo se propone dar cuenta de las relaciones entre el catolicismo post-conciliar y los Montoneros en su momento fundacional. Para ello, describe una serie de redes entre sacerdotes y militantes que se desenvolvieron entre 1966 y 1973 y que constituyen ejemplos significativos del fenómeno. A partir de ellas se ilustra el tipo de vínculo social que se generaba en estos espacios sociales y cómo éste impregnó luego la opción por la militancia insurreccional. De esta manera se intenta polemizar con una serie de ideas con respecto a los vínculos entre el catolicismo y los Montoneros y establecer un marco de comprensión de las relaciones entre religión y política en la conformación de un actor colectivo.
Este trabajo se enmarca en el proyecto de investigación "Ética católica y acción política. Los Montoneros 1966-1976", dirigido por el Dr. Fortunato Mallimaci. Facultad de Ciencias Sociales, UBA.

\section{Summary}

This article searches relationships between Catholicism and Montoneros. Wherefore, main networks built by priest and militants between 1966 and 1973, period of Montoneros's growth, are explored. This argument is able to illustrate relationships between religion and politics in the conformation of a political actor and serves to underline that religion isn't only an element to conserve the status quo. 